\title{
PEMBUATAN BIOETHANOL DARI LIMBAH AMPAS PATI AREN DENGAN METODE HIDROLISIS ENZIMATIS MENGGUNAKAN ENZIM LIGNINOLITIK DARI JAMUR PELAPUK PUTIH
}

\author{
Dwi Dayatmo ${ }^{1}$, Hartini HS $^{2}$ \\ 1,2 Jurusan Teknik Kimia, Fakultas Teknik \\ Universitas Muhammadiyah Jakarta \\ har_tin27@yahoo.co.id
}

\begin{abstract}
ABSTRAK. Proses pembuatan bioethanol dari lignosellulose terdiri dari 3 tahap, yaitu tahap pendahuluan, tahap hidrolisa, dan tahap fermentasi. Penelitian ini bertujuan untuk mengetahui kondisi optimum dari penambahan kadar katalis pada tahap perlakuan pendahuluan terhadap kemampuan pendegradasian lignin dan jumlah enzim ligninolitik jamur pelapuk putih pada tahap hidrolisa terhadap kadar gula reduksi. Dalam pembuatan bioetanol ini menggunakan variabel bebas meliputi kadar asam yang ditambahkan sebesar $10 \% \mathrm{~b} / \mathrm{b} 20 \% \mathrm{~b} / \mathrm{b}$ dan $30 \% \mathrm{~b} / \mathrm{b}$ pada tahap perlakuan pendahuluan dan jumlah enzim ligninolitik jamur pelapuk putih sebanyak $20 \% \mathrm{~b} / \mathrm{b}, 30 \%$ $\mathrm{b} / \mathrm{b}$ dan $40 \% \mathrm{~b} / \mathrm{b}$ pada tahap hidrolisis. Pada tahap perlakuan pendahuluan, ampas aren yang sudah dikeringkan pada suhu $100^{\circ} \mathrm{C}$ digrinding dan dianyak dengan mesh 100 , kemudian didegradasi dengan penambahan $\mathrm{H}_{2} \mathrm{SO}_{4}(10 \% \mathrm{~b} / \mathrm{b} 20 \% \mathrm{~b} / \mathrm{b}$ dan $30 \%$ $\mathrm{b} / \mathrm{b})$ dan diautoklaf pada suhu $121^{\circ} \mathrm{C}$ selama 30 menit. Lalu campuran dinetralkan menggunakan aquadest dan dilanjutkan ke tahap hidrolisa dengan penambahan enzim ligninolitik jamur pelapuk putih $(20 \% \mathrm{~b} / \mathrm{b}, 30 \% \mathrm{~b} / \mathrm{b}$ dan $40 \% \mathrm{~b} / \mathrm{b})$ dan didiamkan selama 2 jam yang bertujuan untuk merombak polisakarida menjadi monosakarida. Hasil penelitian ini menunjukan bahwa kadar asam yang berbeda menyebabkan penurunan jumlah lignin yang berbeda dan penambahan jumlah enzim yang berbeda juga memberikan kadar gula reduksi yang berbeda pula.
\end{abstract}

Kata kunci : Bioethanol, lignosellulose, limbah pati aren

\section{PENDAHULUAN}

Makin menipisnya cadangan bahan bakar fosil di Indonesia perlu solusi untuk memecahkan masalah tersebut, salah satunya dengan menggunakan energi terbarukan yang bisa dibuat dari pemanfaatan bahan alam atau limbah. Sebagai contoh bahan bakar bensin bisa digantikan oleh bahan bakar terbarukan (bioetanol).

Bioetanol merupakan bahan bakar berbasis nabati yang dibuat dari sumber hayati yang mengandung pati, gula dan serat yang keberadaannya sangat melimpah di Indonesia. Proses pembuatan bioetanol dari lignosellulose terdiri dari 3 tahap, yaitu tahap pendahuluan, tahap hidrolisa, dan tahap fermentasi. Perlakuan pendahuluan berfungsi menghilangkan lignin. Tahap perlakuan pendahuluan ini dapat dilakukan dengan menggunakan asam kuat (asam sulfat) dan basa kuat (natrium hidroksida). Tahap kedua adalah tahap hidrolisis yang berfungsi merubah sellulosa yang berupa polisakarida menjadi monosakarida (glukosa). Dalam tahap hidrolisis ini dapat dilakukan secara kimiawi dengan asam atau basa kuat dan secara enzimatis dengan menggunakan enzim pelapuk putih. Hidrolisa secara enzimatis lebih ramah lingkungan dibandingkan hidrolisa secara kimiawi, karena hasil samping dari hidrolisa secara enzimatis ini merupakan bahan yang tidak berbahaya dan mampu diurai kembali oleh alam. Tahap ketiga dalam pembuatan bioethanol adalah tahap fermentasi yang merubah glukosa menjadi ethanol dengan bantuan mikroorganisme Saccharomyces 
cerevisiae dan selanjutnya akan dilakukan proses distilasi untuk menghasilkan bioetanol murni.

Kesempurnaan produksi bioetanol dari limbah lignoselulosa (limbah ampas pati aren) sangat ditentukan oleh tahap hidrolisis enzimatis selulosa menjadi glukosa dan tahap fermentasi glukosa menjadi bioethanol. Oleh karena itu pada penelitian ini akan dipelajari berbagai faktor yang berpengaruh pada masing-masing tahap tersebut.

Ada beberapa permasalahan yang sangat berpengaruh pada tahap hidrolisa enzimatik dari selulosa menjadi glukosa maupun tahap fermentasi glukosa menjadi bioetanol. Untuk itu perlu dikaji kondisi optimum bebrapa faktor yang berpengaruh pada setiap tahap pembuatan bioetanol dari limbah ampas pati aren.

\section{Limbah Ampas Pati Aren}

Aren merupakan tumbuhan berbiji yang dapat dibuat untuk produk pangan dan buahnya dapat dijadikan gula aren. Dalam proses pengolahan gula aren dihasilkan suatu limbah yang berbentuk padat dan cair. Limbah padat (limbah biomassa) dalam proses ini terdiri dari butiran halus, butiran kasar, dan serat kasar. Menurut Firdayati dan Handajani, 2012 menyatakan bahwa limbah biomassa ampas pati aren tersebut masih mempunyai cukup besar komponen $\mathrm{C}$ organik sebesar $69,59 \%$. Melihat kandungan tersebut limbah ini merupakan limbah yang dapat digunakan sebagai sumber bahan baku bioetanol dari lignoselulosa.

\section{Jamur Pelapuk Putih}

Jamur ini berfungsi sebagai pendegradasi lignin pada kayu karena kandungan enzim ekstra selluler ligninolitik di dalamnya. Cara pengambilan enzim ligninolitik dari jamur pelapuk putih adalah dengan mencampurkan jamur ke dalam larutan garam amonium sulfat dan kemudian diendapkan.

\section{Bioetanol}

Etanol disini adalah bioethanol yang berfungsi sebagai bahan bakar dan biasanya digunakan sebagai komponen pencampur bensin beroktan tinggi. Campuran bioetanol kering / absolut terdenaturasi dan bensin pada kadar alkohol sampai dengan sekitar $22 \%$ volume disebut dengan Gasohol. Campuran tersebut dapat meningkatkan nilai oktan bensin. Sebagai contoh, angka oktan bensin premium adalah 87. Setelah dicampur dengan alkohol sebanyak nilai oktan tersebut meningkat (Winarno, 2011). Saat ini bioetanol diproduksi dari tetes tebu, singkong maupun dari jagung. Alternatif lain bahan baku bioetanol yaitu biomassa berselulosa. Selain dikonversi menjadi biofuel, biomassa berselulosa juga dapat mendukung produksi komersial industri kimia seperti asam organik, aseton atau gliserol (Wyman, 2002).

Bahan baku pembuatan bioetanol ini dibagi menjadi tiga kelompok yaitu: bahan sukrosa, bahan berpati, dan bahan berselulosa /lignoselulosa. Bioetanol merupakan bahan bakar alternatif yang diolah dari tumbuhan yang memiliki keunggulan karena mampu menurunkan emisi $\mathrm{CO}_{2}$. Namun bioetanol tersebut harus memenuhi kriteria fuel grade, yaitu harus berkadar kemurnian 99,5\% (Usman, dkk., 2013).

\section{Tahap hidrolisis}

Hidrolisa adalah proses pemecahan selulosa yang berupa polisakarida menjadi monosakarida. Temperatur hidrolisa mencapai $200^{\circ} \mathrm{C}$. Asam encer yang digunakan adalah 0,2-4\% berat (Nguyen, dkk., 2000). Penggunaan asam encer untuk menghidrolisis selulosa biasa mampu mencapai konversi reaksi sampai 50\%. Konsentrasi asam yang digunakan adalah 10-30\% (Badger, 2002).

Metode lain yang digunakan untuk menghidrolisis selulosa adalah secara enzimatis. Enzim merupakan protein alam yang dapat mengkatalisis reaksi tertentu. Proses hidrolisis enzimatik membutuhkan pretreatment 
sehingga enzim dapat berkontak langsung dengan selulosa. Pretreatment dilakukan untuk memecah struktur kristalin selulosa dan memisahkan lignin sehingga selulosa dapat terpisah. Pretreatment dapat dilakukan secara kimia maupun fisik. Metode fisik yang dapat dilakukan adalah dengan menggunakan temperatur dan tekanan tinggi, penggilingan, radiasi, atau pendinginan. Sedangkan metode pretreatmen secara kimia menggunakan solven untuk memecah dan melarutkan lignin (metode delignifikasi) (Mosier, 2005).

$$
\text { Enzim selulase adalah }
$$

campuran enzim dari endoglukanase, eksoglukanase dan $\beta$-glukosidase. Fungi berfilamen seperti Tricoderma dan Aspergillus adalah penghasil selulase (Ul-Haq, et al., 2005). Keuntungan hidrolisis enzimatis dibandingkan dengan hidrolisis asam, adalah tidak terjadi degradasi gula hasil hidrolisis, dapat berlangsung pada suhu rendah, dan memberikan hasil yang tinggi (Taherzadeh dan Karimi, 2007)..

Yang berpengaruh dalam tahap hidrolisa secara enzimatis adalah jenis enzim yang digunakan, jumlah enzim, waktu hidrolisa, temperatur hidrolisa, dan $\mathrm{pH}$ hidrolisa.

Reaksi hidrolisa:

$$
\left(\mathrm{C}_{6} \mathrm{H}_{10} \mathrm{O}_{5}\right) \mathrm{n}+\mathrm{nH} 2 \mathrm{O} \longrightarrow \mathrm{n}\left(\mathrm{C}_{6} \mathrm{H}_{12} \mathrm{O}_{6}\right)
$$

\section{Tahap fermentasi}

Fermentasi dapat dilakukan dengan metode kultur permukaan dan kultur terpendam. Kultur permukaan yang menggunakan substrat padat atau semi padat banyak digunakan untuk memproduksi berbagai jenis asam organik dan enzim. Mikrobia yang umumnya terlibat dalam fermentasi adalah bakteri, khamir dan kapang. Beberapa organisme seperti Saccharomyces dapat hidup, baik dalam kondisi lingkungan cukup oksigen maupun kurang oksigen. Organisme yang demikian disebut aerob fakultatif. Dalam keadaan lingkungan kurang oksigen
Saccharomyces akan melakukan fermentasi. Pada tahap ini lignoselulosa berubah menjadi gula sederhana (glukosa dan fruktosa). Kemudian dilanjutkan dengan proses fermentasi yang berfungsi merubah gula sederhana menjadi alkohol dengan bantuan Saccharomyces cerevisiae. Secara keseluruhan, proses fermentasi akan berjalan baik pada $20-30^{\circ} \mathrm{C}, \mathrm{pH}$ 4.5 -5 dan dalam keadaan anaerob (Sari N.K., 2009).

Reaksi pada tahap fermentasi:

$$
\underset{\text { Glukosa }}{\mathrm{C}_{6} \mathrm{H}_{12} \mathrm{O}_{6}} \underset{\text { Ethanol }}{2 \mathrm{C}_{6} \mathrm{H}_{5} \mathrm{OH}+2 \mathrm{CO} 2}
$$

\section{Tahap pemurnian}

Tahap pemurnian berfungsi untuk memisahkan etanol dari larutan hasil fermentasi yang sebagian besar adalah air. Larutan disentrifuse dan dipisahkan dari padatan yang terikut sehingga sampel siap dianalisa secara kualitatif dan kuantitatif.

Berdasarkan susunan selulosa yang merupakan polisakarida dan adanya potensi selulosa untuk dikonversi menjadi bioetanol, maka selulosa sangat berpotensi untuk dijadikan sebagai bahan baku etanol.

Pada proses pretreatment dilakukan dengan metode fisik, yaitu dengan mencacah menjadi ukuran kecil. Setelah proses pretreatment, proses delignifikasi akan berjalan seiring dengan proses hidrolisis. Dengan menggunakan katalis asam, selulosa yang terkandung dalam ampas aren dapat terlarut dan mendegradasinya menjadi glukosa. Semakin besar konsentrasi katalis yang digunakan diharapkan akan menghasilkan kadar glukosa yang lebih banyak sampai batas tertentu sehingga glukosa yang didapat bisa difermentasi menjadi bioetanol dan didapat kadar konversi optimum bioetanol yang dihasilkan.

\section{METODOLOGI PENELITIAN Alat Penelitian}

Alat penelitian yang digunakan ; 
baskom, fermentor, labu distilasi , pendingin leibig, bunsen, tripot, kasa asbes, corong buchner, selang, statif dan klem, autoklaf, oven, beakerglass, corong, erlenmeyer, buret.

\section{Bahan Penelitian}

Bahan yang digunakan adalah ; limbah ampas aren, Saccharomyces cerevisiae, enzim ligninolitik pada jamur pelapuk putih, asam sulfat, garam amonium sulfat, air, urea (nutrien), asam acetat, $\mathrm{CuSO}_{4} .5 \mathrm{H}_{2} \mathrm{O}, \mathrm{KI}$, $\mathrm{Na}_{2} \mathrm{~S}_{2} \mathrm{O}_{3}$, Asam Sitrat, batu didih, indikator amilum, indikator pp, $\mathrm{HCl}$, $\mathrm{NaOH}$.

\section{Metode Penelitian}

\section{Pembuatan ekstrak jamur pelapuk putih}

Jamur pelapuk putih diblender bentuk bubur, saring kemudian diambil filtratnya.

2. Perlakuan pendahuluan bahan baku (limbah ampas pati aren)

Ampas aren dioven pada suhu $100^{\circ} \mathrm{C}$, kemudian digrinding dan discreening dengan mesh 100 (variabel bebas). Serbuk ampas aren diukur kadar air kemudian $25 \mathrm{gr}$ ampas aren ditambah dengan larutan $\mathrm{H}_{2} \mathrm{SO}_{4} 10 \%$; $20 \%$; dan $30 \%$ (b/b). Larutan ampas dan asam diautoklaf pada suhu $121^{\circ} \mathrm{C}$ selama 30 menit.

\section{Tahap hidrolisis}

Hasil perlakuan pendahuluan akan dipisahkan antara padatan dengan filtratnya. Padatan yang dihasilkan akan dicuci dengan air hingga filtrat netral. Setelah itu padatan akan dikeringkan pada suhu $65^{\circ} \mathrm{C}$ sampai berat konstan dan dianalisa gula reduksi. Kemudian dilanjutkan dengan penambahan ekstrak jamur pelapuk putih (20\%; $30 \%$; dan $40 \%$ ) dan dihidrolisa dengan cara diinkubasi pada suhu $50^{\circ} \mathrm{C}$ selama 1 jam pada $\mathrm{pH}$ 3. Dari hasil hidrolisa tersebut dianalisa kadar gula pereduksi.

\section{Tahap fermentasi}

Larutan hasil hidrolisa kemudian difermentasi menggunakan fermipan dan diperam selama 8; 10; dan 12 hari. Setelah itu hasil fermentasi dipisahkan dengan cara sentrifuse, untuk kemudian dianalisa baik secara kualitatif maupun kuantitatif kadar ethanol dan analisa gula reduksinya.

\section{Metode Analisa}

1. Perlakuan pendahuluan bahan baku (limbah ampas pati aren)

Ampas aren dikeringkan pada suhu $100^{\circ} \mathrm{C}$ dengan menggunakan oven, lalu mengecilkan ukuran ampas aren dengan alat size reduction dan diayak dengan mesh 100 (variabel bebas), komposisi awal ampas aren kering dianalisis yang meliputi analisa kadar lignin dan air lalu menambahkan larutan $\mathrm{H}_{2} \mathrm{SO}_{4} 10 \%, 20 \%$, dan $30 \%$ (variabel bebas) pada ampas aren kering tersebut lalu memananaskan campuran ampas aren dengan larutan $\mathrm{H}_{2} \mathrm{SO}_{4}$ sesuai dengan variabel bebas yang digunakan ke dalam autoclave pada suhu $121^{\circ} \mathrm{C}$ selama 30 menit.

\section{Tahap hidrolisis}

Padatan dan filtrat hasil pemanasan pada autoclave dipisahkan, kemudian padatannya dicuci dengan aquadest sampai filtrate netral. Padatan dikeringkan pada suhu $65^{\circ} \mathrm{C}$ sampai berat konstan dan dianalisa kadar air dan gula reduksi. Kemudian dilanjutkan dengan penambahan ekstrak jamur pelapuk putih dan dihidrolisa dengan cara diinkubasi pada suhu $50^{\circ} \mathrm{C}$ selama 1 jam pada $\mathrm{pH}$ 3. Dari hasil hidrolisa tersebut dianalisa kadar gula pereduksi.Setelah itu dipisahkan antara larutan glukosa dan padatannya.

\section{Tahap fermentasi}

Larutan glukosa hasil hidrolisa dikondisikan $\mathrm{pH} 4$ dengan penambahan

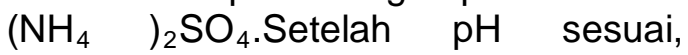
kemudian pada larutan glukosa ditambah dengan ragi (Saccharomycescerevisiae) sebanyak $20 \%$ dan dilakukan proses fermentasi selama 8, 10, dan 12 hari. (variabel bebas)

\section{Tahap pemurnian}

Setelah fermentasi, larutan dikeluarkan dari fermentornya. Larutan 
disentrifuse dan dipisahkan dari padatan yang terikut sehingga sample siap dianalisa dengan alat instrument Alcolyzer untuk uji kadar alcohol yang dihasilkan.

\section{Analisa hasil}

a) Kadar gula reduksi dianalisa dengan metode Luff Schrooll. Pembuatan larutan Luff Schrooll :

1. $25 \mathrm{gr} \mathrm{CuSO}_{4} \quad 5 \mathrm{H}_{2} \mathrm{O}$ dilarutkan dalam $10 \mathrm{ml}$ aquadest

2. $50 \mathrm{gr}$ asam sitrat dilarutkan dalam $100 \mathrm{ml}$ aquadest

3. $388 \mathrm{gr} \mathrm{Na}_{2} \mathrm{CO}_{3} 10 \mathrm{H}_{2} \mathrm{O}$ dilarutkan dalam $400 \mathrm{ml}$ air mendidih

4. Kemudian larutan asam sitrat ditambahkan dalam larutan $\mathrm{Na}_{2} \mathrm{CO}_{3}$ sedikit demi sedikit ( hati-hati terbentuk busa / buih)

5. Kemudian tambahkan Larutan $\mathrm{CuSO}_{4}$ kedalam larutan diatas

6. Encerkan larutan luff kedalam labu takar $1000 \mathrm{ml}$ dengan aquadest sampai batas

b.) Analisa Gula Reduksi

1. $10 \mathrm{ml}$ larutan sampel $+25 \mathrm{cc}$ larutan luff schrooll $+20 \mathrm{cc}$ aquadest + batu didih dalam Erlenmeyer

2. Tutup Erlenmeyer dengan pendingin balik. Didihkan usahakan 2 menit mendidih ) selama 10 menit dengan api sedang.

3. Larutan kemudian didinginkan dengan air es, kemudian ditambah $10 \mathrm{ml}$ larutan $\mathrm{KI}$ 20\% ditambah $10 \mathrm{ml}$ larutan $\mathrm{H}_{2} \mathrm{SO}_{4}$ (1:4).

4. Kemudian larutan ditritasi dengan larutan standar $\mathrm{Na}_{2} \mathrm{~S}_{2} \mathrm{O}_{3}$ sampai titik akhir titrasi.

5. Catat volume tritasi.

a) Tritasi Blanko
1. $10 \mathrm{ml}$ aquadest $+25 \mathrm{cc}$ larutan luff schrooll $+20 \mathrm{cc}$ aquadest +batu didih

2. Pasang pendingin balik, panaskan ( usahakan 2 menit mendidih ). Pendidihan dilakukan 10 menit dengan api sedang.

3. Kemudian dinginkan dengan air es

4. Tambahkan $10 \mathrm{ml}$ larutan $\mathrm{KI}$ $20 \%+10$ ml larutan H2SO4 $(1: 4)$

5. Kemudian larutan ditritasi dengan larutan standar $\mathrm{Na}_{2} \mathrm{~S}_{2} \mathrm{O}_{3} \quad 0,1 \quad \mathrm{~N}$ sampaimuda (coklat tuakuning muda)

6. Tambah 1 pipet indicator amylum, kemudian titrasi dilanjutkan sampai titik akhir titrasi (biru tua-jernih)

7. Catat volume tiritasi

8. Hitung kadar pati tersebut

\section{Perhitungan Analisis:}

Selisih titrasi

Kadar Gula $=\frac{W i}{W} \times F p \times 100 \%$

Keterangan:

Wi = Glukosa yang

dihasilkan dari daftar Luff Schrool

(mg)

$\mathrm{W} \quad=$ Bobot contoh (mg)

$\mathrm{Fp} \quad=$ Faktor pengenceran 


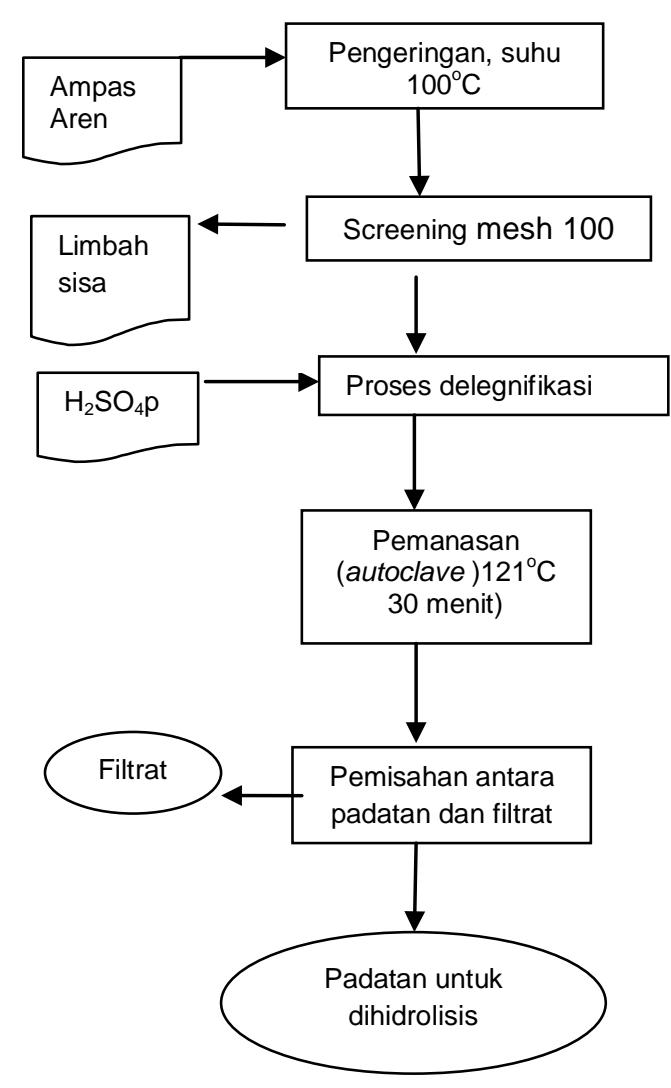

\section{HASIL DAN PEMBAHASAN}

\section{Tahap perlakuan pendahuluan}

Sampel ampas aren yang telah dikeringkan, lalu diayak menggunakan mesh 100. Kemudian dilakukan pengujian penurunan jumlah lignin dengan menggunakan $\mathrm{H}_{2} \mathrm{SO}_{4}$ dengan konsentrasi tertentu. Hasil pengamatan dapat dilihat pada Tabel.1

Tabel 1 pengaruh kadar $\mathrm{H}_{2} \mathrm{SO}_{4}$ terhadap penurunan jumlah lignin

\begin{tabular}{ccc}
\hline Ukuran Mesh & $\begin{array}{c}\text { Penambahan } \\
\mathrm{H}_{2} \mathrm{SO}_{4} \text { pekat } \\
(\mathrm{ml})\end{array}$ & $\begin{array}{c}\text { Penurunan } \\
\text { Jumlah Lignin } \\
(\%)\end{array}$ \\
\hline \multirow{3}{*}{100} & 10 & 38,86 \\
\cline { 2 - 3 } & 20 & 43,62 \\
\hline & 30 & 48,20 \\
\hline
\end{tabular}

Gambar 1. Diagram Alir Penelitan
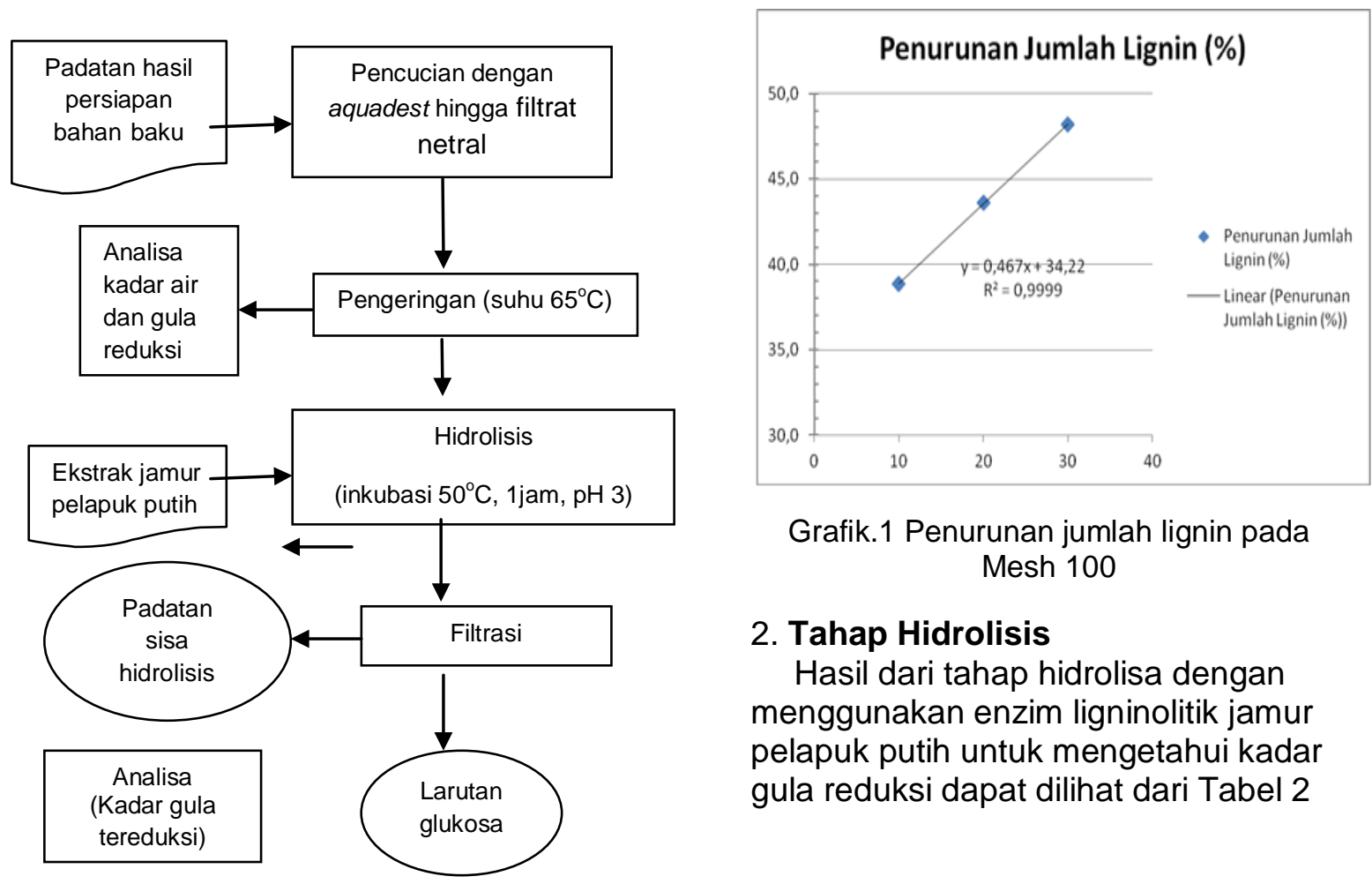

Grafik.1 Penurunan jumlah lignin pada Mesh 100

\section{Tahap Hidrolisis}

Hasil dari tahap hidrolisa dengan menggunakan enzim ligninolitik jamur pelapuk putih untuk mengetahui kadar gula reduksi dapat dilihat dari Tabel 2 


\begin{tabular}{|c|c|c|c|}
\hline \multicolumn{4}{|c|}{$\begin{array}{l}\text { Table } 2 \text { pengaruh jumlah enzim jamur } \\
\text { pelapuk putih terhadap kadar gula } \\
\text { reduksi yang dihasilkan }\end{array}$} \\
\hline $\begin{array}{l}\text { Ukuran } \\
\text { mesh }\end{array}$ & $\begin{array}{c}\text { Penambahan } \\
\mathrm{H}_{2} \mathrm{SO}_{4(\mathrm{~b} / \mathrm{b})}\end{array}$ & $\begin{array}{c}\text { Penambahan } \\
\text { Enzym } \\
\text { Lignolitik }\end{array}$ & $\begin{array}{c}\text { Gula } \\
\text { Reduksi } \\
\text { (\%) }\end{array}$ \\
\hline \multirow{9}{*}{100} & \multirow{3}{*}{10} & 20 & 2,04 \\
\hline & & 30 & 2,09 \\
\hline & & 40 & 2,44 \\
\hline & \multirow{3}{*}{20} & 20 & 2,69 \\
\hline & & 30 & 2,89 \\
\hline & & 40 & 3,04 \\
\hline & \multirow{3}{*}{30} & 20 & 3,24 \\
\hline & & 30 & 3,53 \\
\hline & & 40 & 3,75 \\
\hline
\end{tabular}

optimum yang dibutuhkan untuk mendapatkan bioetanol.

Tabel 3. Kadar setelah fermentasi selama 8

\begin{tabular}{|c|c|c|c|}
\hline $\begin{array}{c}\text { Ukuran } \\
\text { Mesh }\end{array}$ & $\begin{array}{l}\text { Penambahan } \\
\mathrm{H}_{2} \mathrm{SO}_{4} \text { pekat } \\
\text { (ml) }\end{array}$ & $\begin{array}{l}\text { Penambahan } \\
\text { Enzim } \\
\text { Ligninolitik } \\
\text { (\%) }\end{array}$ & $\begin{array}{c}\text { Kadar } \\
\text { Etanol } \\
\text { setelah } \\
\text { fermentasi } \\
(\%)\end{array}$ \\
\hline \multirow{9}{*}{100} & \multirow{3}{*}{10} & 20 & 0,47 \\
\hline & & 30 & 0,53 \\
\hline & & 40 & 0,63 \\
\hline & \multirow{3}{*}{20} & 20 & 0,57 \\
\hline & & 30 & 0,66 \\
\hline & & 40 & 0,77 \\
\hline & \multirow{3}{*}{30} & 20 & 0,72 \\
\hline & & 30 & 0,81 \\
\hline & & 40 & 0,92 \\
\hline
\end{tabular}

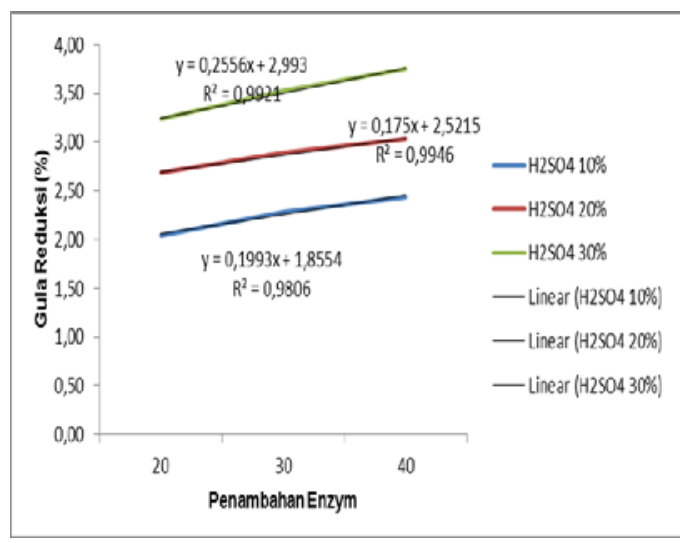

Grafik. 2 Kadar Gula pereduksi terhadap penambahan Enzym

Ligninolitik pada Mesh 100

\section{Tahap Fermentasi}

Setelah proses hidrolisis dilanjutkan ke tahap fermentasi, mengubah glukosa yang terbentuk menjadi bioetanol. Larutan glukosa hasil hidrolisa dikondisikan $\mathrm{pH} 4$ dengan penambahan $\left(\mathrm{NH}_{4}\right)_{2} \mathrm{SO}_{4}$. Setelah $\mathrm{pH}$ sesuai, kemudian pada larutan glukosa ditambah dengan ragi (Saccharomyces cerevisiae) sebanyak 20\%; 30\%; dan $40 \%$ kemudian dilakukan proses fermentasi selama 8, 10, dan 12 hari. Sehingga dapat diketahui waktu

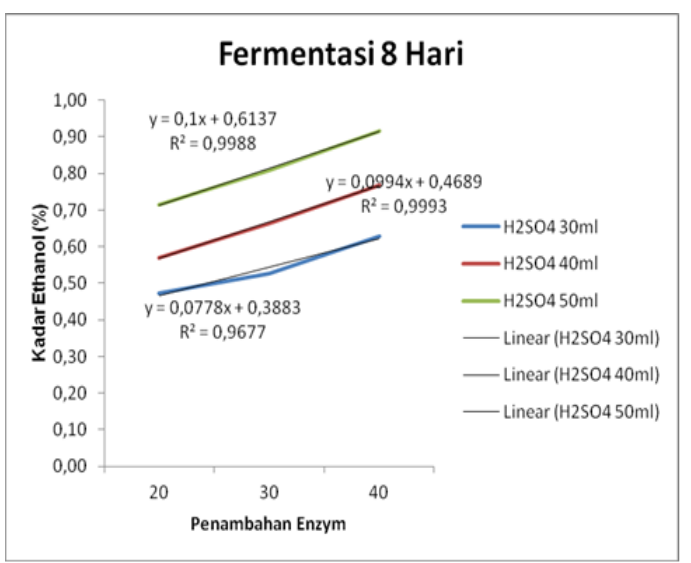

Grafik. 3 Kadar Etanol waktu fermentasi 8 hari dengan mesh 100

Tabel 4. Kadar Ethanol setelah fermentasi selama 10 hari

\begin{tabular}{cccc}
\hline \multirow{2}{*}{$\begin{array}{c}\text { Ukuran } \\
\text { Mesh }\end{array}$} & $\begin{array}{c}\text { Penambahan } \\
\mathrm{H}_{2} \mathrm{SO}_{4} \text { pekat } \\
(\mathrm{ml})\end{array}$ & $\begin{array}{c}\text { Penambahan } \\
\text { Enzim } \\
\text { Ligninolitik } \\
(\%)\end{array}$ & $\begin{array}{c}\text { Kadar } \\
\text { Etanol } \\
\text { setelah } \\
\text { fermentasi } \\
(\%)\end{array}$ \\
\cline { 2 - 4 } 100 & 10 & 20 & 0,56 \\
\cline { 2 - 4 } & 20 & 30 & 0,62 \\
\cline { 2 - 4 } & & 30 & 0,70 \\
\hline
\end{tabular}




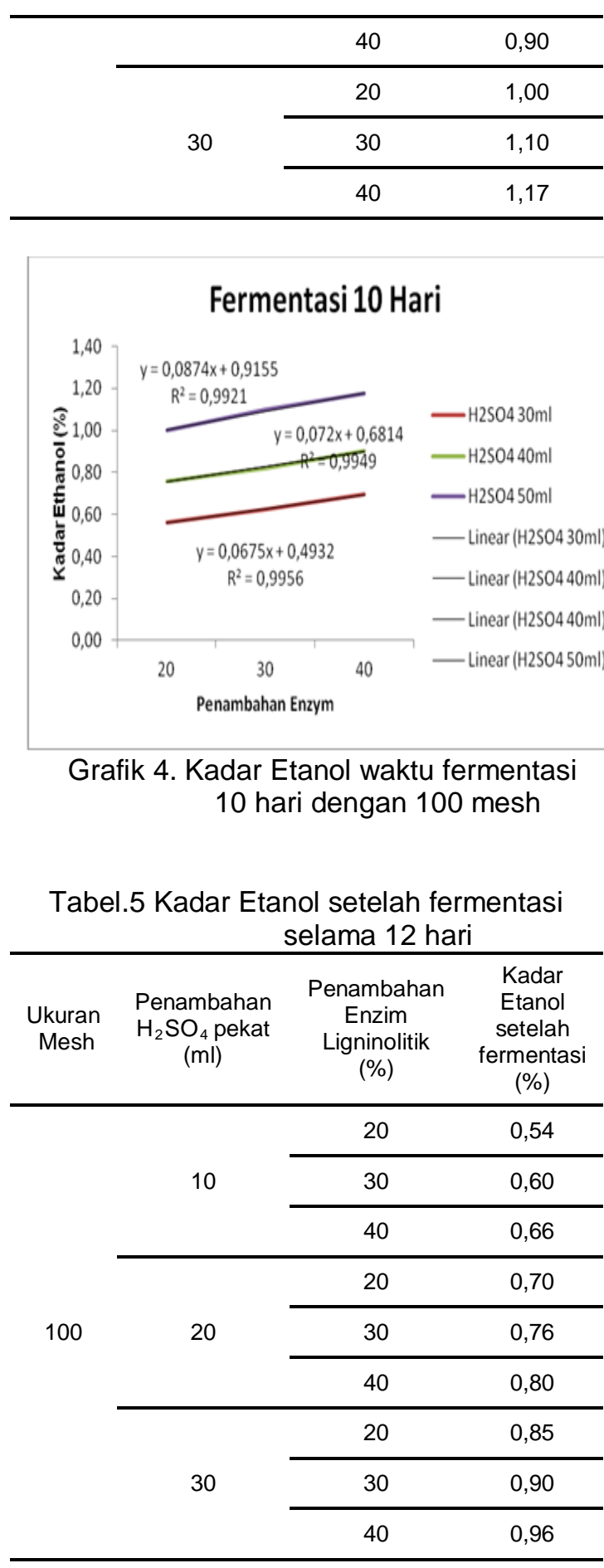

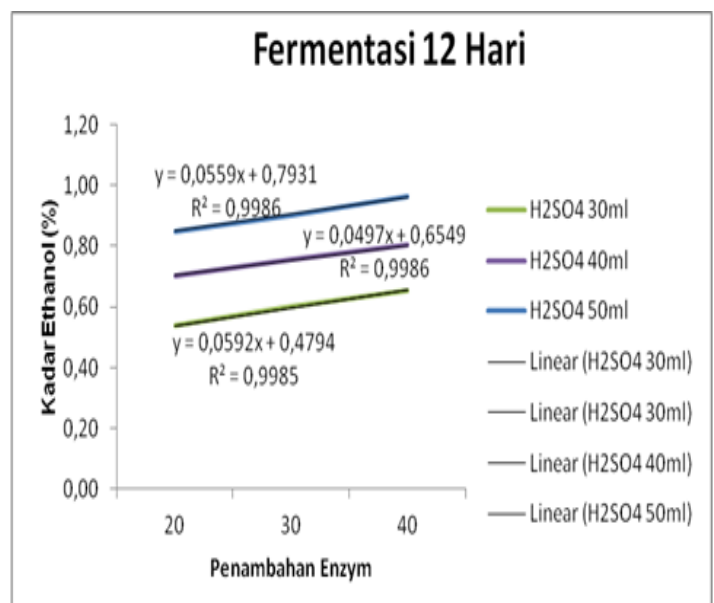

Grafik 5 Kadar Etanol waktu fermentasi 12 hari dengan mesh 100

\section{Pembahasan}

\section{Kadar lignin pada tahap persiapan sampel}

Untuk memperoses ampas aren menjadi bioetanol, tahap pertama yang perlu dilakukan adalah proses pendahuluan. Yakni dengan cara mengeringkan lalu mengayak sampel melalui mesh untuk memperkecil ukuran partikel, sehingga dapat menghasilkan hasil yang optimal dan mempermudah proses selanjutnya.

Setelah melalui proses preparasi secara fisik, lalu dilanjutkan dengan proses kimiawi yakni dengan menambahkan asam kuat. Dalam hal ini menggunakan $\mathrm{H}_{2} \mathrm{SO}_{4}$ yang berfungsi untuk memecah kandungan lignin sehingga akan mempermudah perubahan lignosellulosa menjadi sellulosa. Pada saat penambahan $\mathrm{H}_{2} \mathrm{SO}_{4}$, yang digunakan sebagai variabel bebas. Untuk mengetahui apakah dengan semakin banyak penggunaan asam maka akan berpengaruh terhadap besarnya nilai kadar lignin dalam proses preparasi sampel.

\section{Kadar gula pereduksi pada tahap} hidrolisis

Dalam penelitian ini variabel bebas yang dilakukan adalah perbandingan banyaknya jumlah enzim ligninolitik dari jamur pelapuk putih yang digunakan dalam proses hidrolisis. Sehingga dapat diketahui perbandingan yang 
dapat menghasilkan nilai gula pereduksi yg optimal. Kadar gula pereduksi dianggap sebagai representasi dari kadar polisakarida yang telah dipecah menjadi monosakarida, dalam hal ini berupa selulosa. Oleh karena itu dilakukan pengamatan terhadap kadar lignin sebelum proses hidrolisis.

Pada tahap hidrolisis ini dapat diketahui dari hasil analisa sampel, semakin banyak jumlah enzim yang digunakan maka akan semakin mempermudah proses hidrolisis sehingga kadar gula pereduksi juga semakin tinggi. Berkurangnya kadar lignin pada sampel ampas aren akan memaksimalkan kontak enzym dalam merubah selulosa menjadi glukosa. Dengan demikian jumlah asam kuat yang digunakan saat proses persiapan sampel juga sangat berpengaruh dalam mengoptimalkan kadar gula pereduksi, yang kemudian dilanjutkan ketahap fermentasi untuk mengubah glukosa menjadi bioetanol.

\section{Kadar Bioetanol dari proses fermentasi}

Pada tahap fermentasi selain jenis, jumlah dan juga suhu pada saat fermentasi, waktu fermentasi juga memegang peranan yang cukup penting untuk mendapatkan hasil akhir fermentasi yang optimal. Oleh karena itu pada penelitian ini ingin memperhatikan waktu optimum yang dapat digunakan untuk menghasilkan ethanol dalam jumlah maksimal.

Dari data yang ada dapat disimpulkan, pada hari ke 10 etanol yang dihasilkan dari proses fermentasi berada pada kondisi maksimal. Namun pada hari ke 12 hasil fermentasi mengalami penurunan, hal ini mungkin dikarenakan kemampuan mikroba untuk mengubah glukosa menjadi ethanol bekurang. Atau disebabkan munculnya gangguan dari mikroba lain, karena waktu yang terlalu lama.

\section{KESIMPULAN}

Dari hasil penelitian ini dapat diambil kesimpulan sebagai berikut :

1. Ampas aren sebagai limbah yang tersedia dalam jumlah besar memiliki potensi besar untuk dimanfaatkan sebagai bahan baku dalam pembuatan bioetanol, karena kandungan selulosa yang cukup banyak dan proses pretreatment yang tidak rumit.

2. Semakin tinggi kandungan asam kuat yang digunakan maka jumlah selulosa yang bisa terkonversi semakin banyak, karena kandungan lignin yang menjadi penghalang selulosa untuk terhidrolisis semakin sedikit

3. Pemakaian semakin banyak enzym sebagai katalis untuk membantu proses hidrolisis semakin baik, sehingga dapat banyak memecah polisakarida menjadi monosakarida.

\section{Daftar Pustaka}

Badger, P.C. 2002. Ethanol from cellulose: A general review. p. 17-21. In J. Janick and A. Whipkey (Ed.). Trends in New Crops and New Uses. ASHS Press, Alexandria, VA.

Firdayati,M., Handajani, M., 2012. Studi Karaktersitik Dasar Limbah Industri Tepung Aren. Unnes Journal of Biology Education, Volum 1 No 1.

Mosier, N., Wyman, C., Dale, B., Elander, R., Lee, Y.Y., Holtzapple, M., Ladisch,M. 2005. Features of promising technologies for pretreatment of lignocellulosic biomass. Bioresource Technology 96 (2005) 673-686

Nguyen, Q. A., Tucker, M. P., Keller, F. A., \& Eddy, F. P., 2000. Two-stage dilute-acid pretreatment of softwoods. Applied Biochemistry and Biotechnology, 84-86, 561-576 
Sari, N.K., 2009. KAJIAN PRODUKSI BIOETHANOL DARI RUMPUT GAJAH. ARTICLES CHEMICAL ENGINEERING SEMINAR SOEBARDJO BROTOHARDJONO VI " Waste Based Energy and Chemicals. Surabaya

Taherzadeh, M.J. dan Karimi, K., Acidbased Hydrolysis Processes for Ethanol from Lignocellulosic Materials: a review, 2007, Bioresources 2(3), pp. 472-499.

Ul-Haq, I., Javed, M. M., Khan, T. S., and Siddiq, Z., 2005, Cotton Saccharifying Activity of Cellulases Produced by Co-culture of Aspergillus Niger and Trichoderma Viride, Research Journal of Agriculture and Biological Sciences, 1(3): 241-245.

Usman, B., Dwinanda, L., Huda, N., 2013. Modul STRATEGI PEMASARAN BIOETANOL DAN PEMANFAATAN LIMBAH INDUSTRI BIOETANOL. DIKLAT TEKNOLOGI BIOETANOL BAGI GURU SMK. Kementerian Pendidikan dan Kebudayaan Pusat Pengembangan Pemberdayaan Pendidik dan Tenaga Kependidikan Bidang Mesin dan Teknik Industri/ TEDC Bandung

Winarno, J. 2011. Studi Eksperimental Pengaruh Penambahan Bioetanol pada Bahan Bakar Pertamax terhadap Unjuk Kerja Motor Bensin. Jurnal Teknik, Vol 1 No 1. Janabadra

Wyman, Carles E. 2002. Handbook on Bioethanol : Production and Utilization. Biofuels Information Center. 